\title{
АНАЛІЗ РОЗВИТКУ ТЕХНІЧНОГО ОСНАЩЕННЯ СУЧАСНИХ ВИСОКОШВИДКІСНИХ РЕЙКОВИХ ПОЇЗДІВ
}

Канд. техн. наук А.М. Зіньківський

\author{
АНАЛИЗ РАЗВИТИЯ ТЕХНИЧЕСКОГО ОБОРУДОВАНИЯ СОВРЕМЕННЫХ \\ ВЫСОКОСКОРОСТНЫХ РЕЛЬСОВЫХ ПОЕЗДОВ
}

Канд. техн. наук А.Н. Зиньковский

\section{ANALYSIS OF THE DEVELOPMENT OF TECHNICAL EQUIPMENT MODERN HIGH-SPEED RAIL TRAINS}

PhD, A. Zinkivskyi

Проведено аналіз зміни основних елементів залізничного високошвидкісного рухомого складу краӥн світу, встановлено напрямки, мету та необхідність його удосконалення. Визначено необхідність та методи покрамення динаміки руху поӥзда за рахунок застосування екіпажної частини різних розмірів з урахуванням методів підвішування тягової передачі. Встановлено методи забезпечення зменшення опору руху поӥзда. Розглянуто методи зв'язку екіпажної частини поӥзда з кузовом, їх особливості.

Ключові слова: високошвидкісний рухомий склад, швидкість руху, візки, струмоприймачі, системи гальмування, технічне оснащення.

Проведен анализ изменения основных элементов железнодорожного высокоскоростного подвижного состава стран мира, установлены направления, цели и необходимость его совершенствования. Определена необходимость и методь улучиения динамики движения поезда за счет применения экипажной части различных размеров с учетом методов подвешивания тяговой передачи. Установлень методы обеспечения уменьшения сопротивления движению поезда. Рассмотрены методы связи экипажной части поезда с кузовом, их особенности.

Ключевые слова: высокоскоростной подвижной состав, скорость движения, тележки, токоприемники, системы торможения, техническое оснащение.

Analyzed changes in the basic elements of a high-speed railway rolling stock of the world. Certain countries in which high-speed motion was adopted first. Directions, purpose and need for improved systems and design details. Defined limiting factors for increasing speed. Methods to improve the dynamics of the train by applying changes ekipazhnoyi use of trains and trucks of different sizes based methods of transmission and suspension traction elements spring suspension which provide smooth movement on the straight and curved sections of track. Established methods to ensure reduction of resistance of the train and passive protection of train collisions. Methods of communication ekipazhnoyi train with the body, their features. The analysis of high-speed trains braking systems and application combinations to ensure safety at different speeds. The construction pantograph that provides the necessary dynamic properties of high-speed train, provided a high level of reliability and current collection. An optimal voltage value for the operation of electric rolling at high speeds.

Keywords: High rolling stock, speed, truck, current collectors, braking systems, technical equipment. 
Вступ. У 19-му і на початку 20-го сторіччя залізничні потяги були єдиною формою громадського транспорту. Залізничні компанії в Європі та Сполучених Штатах для боротьби з наступаючими літаками в тридцятих роках використовували високошвидкісні паровози зі швидкістю 130-160 км/год. Друга світова війна призупинила розвиток швидкісного транспорту. У 1957 р. компанія «Odakyu Electric Railway» 3 Токіо створила Romancecar 3000 SSE. Ця система вузькоколійних поїздів 3 максимальною швидкістю 145 км/год дала японцям віру в те, що вони можуть благополучно будувати ще більш швидкі поїзди без перебудови колій.

Першою у світі "високошвидкісною залізницею" стала «Tōkaidō Shinkansen», офіційно відкрита в жовтні 1964 р. (будівництво почалося в 1959 р.). Потяги Shinkansen нульової серії, побудовані Кавасакі, досягали швидкості в 200 км/год (середня швидкість 160 км/год) на маршруті "Токіо Нагоя - Кіото - Осака".

I в Японії, і у Франції початковим стимулом для введення високошвидкісного залізничного транспорту була потреба в додатковій місткості, щоб задовольнити зростаючий попит на пасажирські залізничні перевезення, що забезпечено будівництвом окремої прямої пасажирської високошвидкісної лінії $[1,2]$.

Постановка проблеми у загальному вигляді та іiі зв'язок із важливими науковими та практичними завданнями. Необхідним етапом у подальшому підвищенні швидкості руху залізничного пасажирського рухомого складу $\epsilon$ застосування надійного оснащення високошвидкісних поїздів. Дане завдання виконується на основі розробки нових, а також розвитку та удосконалення існуючих систем та вузлів рухомого складу під пильним наглядом науковців для забезпечення безпеки руху на транспорті та життя користувачів (пасажирів) і працівників.

Аналіз останніх досліджень i публікацій. В другій половині ХХ століття розвинутими країнами було проведено велику кількість досліджень зі створення нових систем і вузлів високошвидкісного руху пасажирських поїздів та впроваджено їх в експлуатацію, зокрема для підвищення швидкості та плавності руху, безпеки руху та пасажирів, комфорту користувачів [3-10].
Визначення мети та задачі дослідження. Провести аналіз даних 3 експлуатації існуючих та розробки нових систем i вузлів ВШРС для формування напрямків підвищення надійності та швидкості рухомого складу.

Основна частина дослідження. В останнє десятиліття на залізничному транспорті йшло інтенсивне освоєння швидкостей 250-300 км/год, для чого у Франції, Англії, ФРН, Італії, Японії були розгорнуті широкі теоретичні та експериментальні дослідження i насамперед у напрямі вдосконалення ходових частин і тягового привода.

Із загальних вимог до механічної частини стосовно високошвидкісного рухомого складу (ВШРС) домінуючими стали вимоги безпеки руху та комфорту без зниження технікоекономічної ефективності.

На перший план вийшли проблеми забезпечення динамічної стійкості візків, зменшення реакцій на збурення кінематичного характеру, а також здатність ВШРС тривало зберігати свої динамічні характеристики в процесі експлуатації.

Були створені прототипи високошвидкісних поїздів (ВШП), на яких перевірялися $\mathrm{i}$ відпрацьовувалися конструктивні рішення, що забезпечують безпеку руху в умовах високих швидкостей. Далеко не всі запропоновані спочатку конструкції виявилися ефективними та життездатними.

При проектуванні оцінювався ступінь ризику розрахунковим, експериментальним, експертним шляхом або за даними експлуатації аналогічних типів високошвидкісного рухомого складу та його складових частин, залізничних ліній, їх підсистем i складових частин підсистем.

ВШРС i його складові частини, підсистеми i складові частини підсистем залізничних ліній, елементи складових частин підсистем за міцністю, стійкістю і технічним станом мають забезпечувати безпечний рух поїздів з найбільшими швидкостями, встановленими відповідним органом виконавчої влади в галузі залізничного транспорту.

Обрані проектувальником конструкції ВШРС та його складових частин, підсистем залізничної лінії та їх складових частин повинні бути безпечні впродовж призначеного терміну служби та (або) ресурсу, призначеного терміну зберігання, витримувати впливи i 
навантаження, яким вони можуть піддаватися в процесі експлуатації.

При проектуванні ВШРС:

- повинні вибиратися рішення, що забезпечують встановлені законодавством країни допустимі рівні небезпечних впливів;

- повинні забезпечуватися вимоги габариту рухомого складу, умов експлуатації 3 урахуванням зовнішніх кліматичних i механічних впливів, технічної сумісності, в тому числі 3 інфраструктурою залізничного транспорту;

- повинні передбачатися енергопоглинаючі пристрої для захисту пасажирів i обслуговуючого персоналу в разі зіткнення залізничного рухомого складу;

- повинні використовуватися програмні засоби, що забезпечують безпеку функціонування високошвидкісного залізничного транспорту та його складових частин.

3 двох можливих підходів до компонування ВСПС - моторвагонного (всі вагони поїзда моторні) i електровозного (головні вагони замінені електровозами) домінуючим став другий, прийнятий скрізь, крім Японії. При цьому було виявлено деякі стійкі тенденції в схемних рішеннях i конструкціях екіпажної частини.

Моторний візок є результатом тривалих пошуків і втіленням ряду принципів створення ходової частини швидкісного електрорухомого складу (ЕРC), в першу чергу спрямованих на досягнення високої динамічної стійкості, тобто на забезпечення виведення критичної швидкості по вилянню візка за межі експлуатаційних швидкостей - 300 км/год. Насамперед цьому сприяє велика база візка в поєднанні 3 високим абсолютним значенням i оптимальним співвідношенням жорсткостей поздовжніх i поперечних буксових зв'язків, а також малою початковою конусністю бандажа $-1 / 40$

Характерно, що прийнятні значення бази і жорсткостей зв'язків були вибрані не відразу, a впродовж більш ніж десятирічних теоретичних і експериментальних досліджень. Двічі у прототипів збільшили базу візки (спочатку 2,6 м, потім 2,9 і 3 м); пошук необхідного співвідношення поздовжньої i поперечної жорсткостей буксових зв'язків призвів до відмови від спочатку прийнятого буксового вузла типу Альстом і переходу до вузла 3 циліндричними гумометалевими напрямними. Він має поздовжні і поперечні жорсткості зв'язку i забезпечує динамічну стійкість при швидкостях 350 км/год до появи ефективної конусності бандажа, що перевищує 0,1, що відповідає пробігу 0,5 млн км.

Другий стабілізуючий фактор зменшення маси візка. Перенісши на кузов кріплення моторно-редукторного блока, вдалося знизити масу візків практично вдвічі. Був також введений гаситель коливань виляння 3 «фрикційною» характеристикою, що забезпечував великий момент тертя при малих швидкостях відносних кутових переміщень візків і кузова. Всі ці рішення збережені і для поїздів 3 максимальною швидкістю в експлуатації 300 км/год.

Суттєвих змін зазнав і вузол зв'язку візка 3 кузовом, в якому спочатку застосовували пневматичні ресори 3 малою поперечної рухливістю, потім кручені пружини «Флексікойл» високої гнучкості, після чого повернулися до пневморесор 3 високою поперечною рухливістю. Відмова від першого рішення була продиктована його конструктивною складністю, викликаною лише вертикальної рухливістю пневморесор, які не могли сприймати поздовжніх деформацій, викликаних проходом кривих, i не мали достатньої гнучкості, необхідної для поперечного зв'язку кузова з візком.

Поєднання високого статичного прогину (283 мм в кузовний ступені підвішування причіпного вагона) 3 великим запасом поперечної стійкості досягається тим, що точка опори кузова на пружини знаходиться на висоті, близькій до рівня положення центру мас кузова.

Стрілоподібна форма кузова в цілому збережена для всіх поїздів, однак лобовій частині поїзда додана ще більш подовжена форма, що на швидкості 300 км/год дозволяє знизити на $10 \%$ аеродинамічний опір руху.

У лобовій частині головного вагона розташована захисна конструкція 3 набору відрізків труб нержавіючої сталі у вигляді двох шарів «бджолиних стільників», яка руйнується при збільшенні поздовжньої сили понад 700 кН і володіє високим поглинанням при аварійному лобовому ударі. Опорна плита «стільників» здатна сприйняти зусилля до 2000 кH і розподілити його між стояками кабіни, не руйнуючись. 
При русі кузов вагона, що спирається на ресорне підвішування візків, піддається коливанням бічної хитавиці. При дуже гнучкому ресорному підвішуванні кути коливань бічної хитавиці можуть досягати великих величин, що призведе до виходу вагона за межі габариту рухомого складу. Бічний нахил в кривій компенсується відцентровою силою, що виникає при проходженні вагоном підвищення зовнішньої рейки.

Буксовий підшипниковий вузол виконаний нерозбірним, попередньо відрегульованим i змащеним герметичним блоком 3 двох конічних підшипників, що не потребує ревізії до пробігу 1,5 млн км.

Щоб уникнути поперечного «розхитування» моторно-редукторного блока, між ним і кузовом введені пружинні механізми, що мають характеристику, вони забезпечують центрування осі блока при русі в прямих ділянках колії і кривих великого радіуса. При русі в кривих малих радіусів (менше 500 м) виникає небезпека появи таких відносних поперечних переміщень підвішеного до кузова редуктора і колісної пари, які не можуть бути сприйняті шарнірно-повідковими вузлами муфти. Щоб уникнути пошкодження муфти на візках, передбачені важільні механізми жорсткого кутового зв'язку рами візка 3 моторно-редукторним блоком, що змушує цей блок слідувати за візком при повороті іiі навколо вертикальної осі, не заважаючи іншим переміщенням. Це забезпечує відносні поперечні переміщення осі колісної пари i редуктора в допустимих межах.

Для доведення максимальної швидкості руху електропоїздів всіх серій до 300 км/год модернізуються експлуатовані поїзди, конструкційна швидкість яких дорівнює 270 км/год. 3 іншого боку, для підготовки до роботи в XXI ст. виробники високошвидкісних поїздів працюють у таких напрямках:

- розробка основних технічних вимог, що забезпечують регулярну i безпечну експлуатацію 3 максимальною швидкістю 350 км/год, для створення поїздів нового покоління;

- відкриття ряду тем науково-дослідних і дослідно-конструкторських робіт для вирішення виникаючих проблем i впровадження надійних, працездатних технічних нововведень, що перевіряються шляхом випробувань дослідних зразків.
Передбачено, що всі поїзди повинні бути оснащені гальмами з системами управління MC3 i електропневматичними пристроями протиюзного захисту, екстреного гальмування при управлінні поїздом в одну особу, а також тягово-гальмівним контролером нового типу. Нижче наведені особливості, технічні та експлуатаційні характеристики гальмівного обладнання для поїздів кожного типу.

Гальмівне зусилля кожного візка при звичайному службовому гальмуванні в діапазоні початкових швидкостей від 200 до 30 км/год повинно бути не менше 36 кН, при екстреному гальмуванні в тому ж діапазоні - не менше 50 кН.

Гальмівне зусилля кожного візка при звичайному службовому гальмуванні в діапазоні початкових швидкостей від 360 до 220 км/год повинно бути не менше 8,5 кН, при повному службовому гальмуванні в тому ж діапазоні - не менше $15 \mathrm{\kappa H}$, при екстреному гальмуванні - не менше $20 \mathrm{\kappa H}$.

Гальмівні диски кріпляться болтами до диска одного 3 коліс кожної колісної пари. Вони діють тільки при швидкості менше 30 км/год, компенсуючи малу ефективність електричних гальм в діапазоні низьких швидкостей, використовуються при маневрових пересуваннях і виконують функції гальма стоянки. Гальмівне зусилля кожного візка повинно бути не менше 25 кН.

На осі кожної колісної пари встановлюють чотири сталевих гальмівних диски зі спеченими керамічними накладками. Гальмівне зусилля кожного візка при швидкості менше 200 км/год повинно бути не менше 40 кН, при швидкості більше 200 км/год - не менше 15 кН.

Проведено випробування 3 метою визначення можливості заміни чотирьох сталевих гальмівних дисків зі спеченими керамічними накладками, що поглинають енергію порядку 90 МДж на кожну колісну пару, трьома такими ж дисками або трьома дисками 3 вуглецевого волокна зі спеченими керамічними накладками (або двома дисками 3 вуглецевого волокна 3 накладками 3 цього ж матеріалу).

Вихрострумове гальмо передбачено використовувати тільки на нових лініях при швидкості більше 220 км/год. За межами цього діапазону застосуванню цього гальма перешкоджає робота системи автоматичного 
регулювання швидкості. Для забезпечення надійності та правильної роботи гальма, запобігання його несвоєчасному спрацьовуванню будуть проведені відповідні дослідження. Намічено провести ресурсні випробування гальма в умовах регулярної експлуатації. Будуть удосконалені пристрої для вимірювання та регулювання повітряного зазора. Науковцям вдалося вирішити проблему забезпечення нечутливості детекторів нагріву букс до температурного впливу вихрострумового гальма. Роботи в цьому напрямку ведуться на залізницях кількох країн Свропи.

Для забезпечення високошвидкісного руху при швидкостях понад 200 км/год на рухомий склад 3 контактної мережі необхідно за допомогою одного або декількох струмоприймачів подати електричну енергію сумарною потужністю до 20000 кВт.

Збільшення потужності високошвидкісних магістралей (ВШМ) обумовлено тим, що при збільшенні швидкості квадратично зростає аеродинамічна складова основного опору руху [11]. Так, якщо при швидкості 120-140 км/год основний питомий опір руху звичайних пасажирських поїздів не перевищує 4 кгс/т, то для високошвидкісного ЕРС (250-300 км/год) він дорівнюе 10-17 кге/т. Відповідно до цього для реалізації високих швидкостей руху потрібна істотно більша питома потужність тягового обладнання поїзда [12].

Забезпечити надійну роботу елементів, що беруть участь в струмозніманні допомогою ковзного електричного контакту при системі тяги постійного струму напругою 3 кВ уявляється досить складним. Дослідні швидкісні поїздки на залізницях у Франції в середині 50-х років минулого століття остаточно підтвердили висновок про те, що живлення постійним струмом напругою 1,5 кВ не має перспектив при швидкостях понад 200 км/год. Використання постійного струму 3 напругою $3 \mathrm{kB}$ вимагає забезпечення струмознімання на один струмоприймач зі струмом $2500 \mathrm{~A}$, а, отже, роботу електропоїзда 3 декількома струмоприймачами.

При русі ЕРС повинні бути виключені удари струмоприймача з елементами підвіски в результаті їх динамічних переміщень. На електровозах i моторних вагонах електропоїздів у країнах СНД і ряді інших держав застосовують струмоприймачі пантографного типу. Їх часто називають пантографами.

Струмоприймачі повинні забезпечувати стійкий контакт 3 проводом. Тому сила натискання полоза на дріт повинна бути досить великою, проте ії не можна збільшувати вище певної межі, оскільки вона призводить до відтискання контактного проводу, його підвищеного зносу та зносу контактних деталей струмоприймача.

Найбільш поширеними для високошвидкісного руху $є$ асиметричні струмоприймачі (див. рис. 1). Такий струмоприймач являє собою багатоважільний механізм 3 шарнірнозчленованих трубчастих рам. Основними вузлами в конструкції струмоприймача $\epsilon$ : полози 2 із закріпленими контактними накладками 1, верхня рама 3 , яка в нижній частині закінчується поперечним кронштейном, сполученим 3 нижнім важелем 4 і тягою 5, підставка 7, закріплена на ізоляторах 8 , i пневматичний привід 6 , встановлений на рамі підставки.

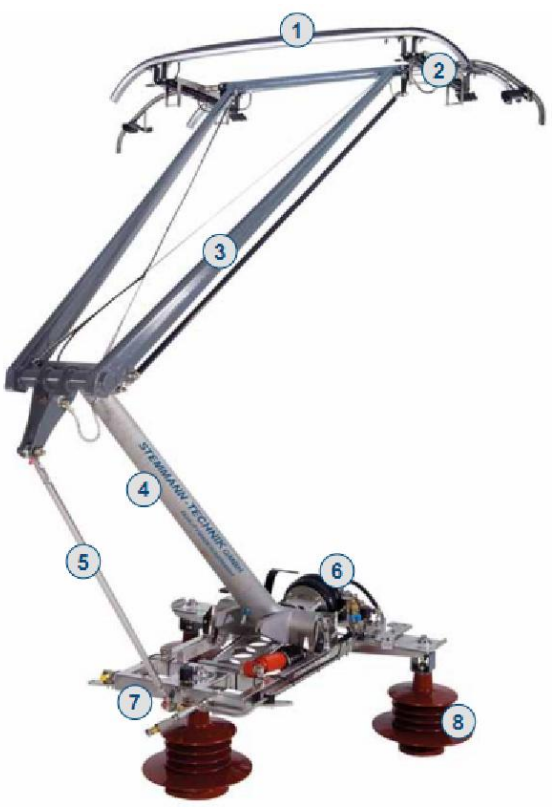

Рис. Асиметричний струмоприймач:

1 - струмознімальна накладка; 2 - полози;

3 - верхня рама; 4 - нижній важіль; 5 - тяга;

6 - пневматичний привід; 7 - підставка;

8 - ізолятори

Переваги асиметричного струмоприймача перед звичайним пантографом:

- менша маса; 
- коливання струмоприймача при русі менше розгойдують елементи контактної мережі, що забезпечує краще притискання полоза струмоприймача до контактного провода i, таким чином, краще струмознімання;

- потрібно менше місця на даху, що полегшує розміщення дахового обладнання. Деякі види електричного рухомого складу, розраховані на роботу з декількома системами електроживлення, мають різні пантографи для різних видів живильного струму;

- менша матеріаломісткість;

- потрібна менша потужність привода для піднімання і опускання струмоприймача.

Вивчення взаємодії контактної підвіски 3 рухомим струмоприймачем показує, що зі збільшенням швидкості руху сила динамічного контактного натискання істотно зростає i, отже, зростає інтенсивність зносу контактних проводів і струмознімальних елементів. Контактне натискання зі збільшенням швидкості має зростати за певним законом, тоді механічне та електричне зношування контактного провода та струмознімальних елементів буде мінімальним.

При високих швидкостях руху неодмінною умовою забезпечення стабільного ковзного контакту між струмознімальними елементами i контактним дротом $\epsilon$ значна ширина полоза струмоприймача, яка повинна становити не менше 400 мм. В силу багатьох причин струмоприймачі на рухомому складі різних європейських країн мають полози різної довжини: у Німеччині, Австрії та Іспанії загальна довжина полоза дорівнює 1950 мм, у Великобританії - 1600 мм, у Франції та Швейцарії - 1450 мм. У колишньому СРСР, а нині в країнах СНД загальна довжина полоза складає 2260 мм [1-12].

Висновки 3 дослідження і перспективи, подальший розвиток у даному напрямку. На основі проведеного аналізу розвитку високошвидкісного рухомого складу можна сказати, що є ще досить великий простір для удосконалення конструкції та напрямків щодо підвищення швидкості руху поїздів. Серед них такі:

- удосконалення конструкції екіпажної частини для забезпечення плавності руху поїзда;

- застосування нових систем гальмування та матеріалів для них 3 метою підвищення граничних швидкостей та збереження безпеки pyxy;

-зменшення загальної маси рухомого складу;

-застосування нових матеріалів та удосконалення конструкції струмоприймачів для покращення процесу струмознімання та зменшення зносу елементів тертя.

\section{Список використаних дюерел}

1. Костромина, И. Японские поезда - симбиоз высоких технологий и комфорта [Текст] / И. Костромина // Вагонный парк. - 2011. - № 1. - С. 46-48. C. 40-43.

2. Кучеренко, О. Быстрее самолета [Текст] / О. Кучеренко // Вагонный парк. - 2010. - № 2. -

3. Soulie C., Tricoire J. Le grand livre du TGV Editions [Текст] / La Vie du Rail 2002, Paris.

4. International Railway Journal, Simons-Boardman [Текст]/Publ. Corp. Ashford/New York, iss. 2/2009, 7/2009, 8/2009, 5/2010.

5. Cherubini F.: Materiale motore 2005 ETR Editrice Transport su Rotaire Salo (Brescia) 2005.

6. Paliotta L., Mosca M.: Dalla Direttissima all'Alta Velocita. Ponte San Nicolo. Duegi Editrice 2007.

7. Railway Gazette Inernational. Reed Press Publishing, Sutton: is. 3/2010, 5/2010, 6/2010, 8/2010.

8. Suda H.: Tokkaido Shinkansen, JTB Can Brooks 2000.

9. Semmens P.: High Speed in japan. Shinkansen - the world's busiest high -speed railway. Second edition, Platform 5 Publishing Ltd. Sheffield 2000.

10. ICE: la grande vitesse allemande a 15 ans. Rail Passion nr 110.

11. Колесов, С.М. Матеріали та взаємодія контактної підвіски і струмоприймача [Текст]: підручник / С.М. Колесов, І.С. Колесов. - Дніпропетровськ: Вид-во Дніпропетр. нац. ун-ту залізн. трансп. ім. акад. В.Лазаряна, 2006. - 284 с. 
12. Беляев, И.А. Токосъем и токоприемники электроподвижного состава [Текст] / И.А. Беляев, В.П. Михеев, В.А. Шиян; под ред. И.А. Беляева. - 2-е изд., перераб. и доп. - М.: Транспорт, 1976. $184 \mathrm{c}$.

Рецензент д-р техн. наук, професор А.П. Фалендиш

Зіньківський Артем Миколайович, канд. техн. наук, кафедра експлуатації та ремонту рухомого складу

Українського державного університету залізничного транспорту. Тел.: (057) 730-19-99. E-mail:

kumasiktem@ukr.net.

Artem Zinkivskyi, candidate of technical Sciences, Department of Operation and repair of rolling stock Ukrainian State University of railway transport. Тел.: (057) 730-19-99. E-mail: kumasiktem@ukr.net.

Наукова праця здана до друку 14.07.2015 року 